\title{
Review: Hepatoprotector Compounds in Plant Extracts
}

\author{
Dichy Nuryadin Zain ${ }^{1,2}$, Riezki Amalia ${ }^{2}$, Jutti Levita ${ }^{2}$ \\ ${ }^{1}$ Sekolah Tinggi Ilmu Kesehatan Bakti Tunas Husada Tasikmalaya \\ Jalan Cilolohan No. 36 Kota Tasikmalaya, 46115 \\ ${ }^{2}$ Department of Pharmacology and Clinical Pharmacy \\ Faculty of Pharmacy, Universitas Padjadjaran \\ Jl. Raya Bandung-Sumedang km.21 Jatinangor, West Java, Indonesia. \\ E-mail korespondensi : dichynuryadinzain@yahoo.com
}

\begin{abstract}
Many plants have been reported to possess hepatoprotective activity. The mechanism has not yet been revealed, but it was predicted due to the antioxidants that could prevent the formation of free radicals produced by hepatotoxins. Of the 30 plants studied, Crocus sativus gave the largest hepatoprotector activity at a dose of $20 \mathrm{mg} / \mathrm{kg}$, followed by Uncaria gambier Roxb. with a dose of $30 \mathrm{mg} / \mathrm{kg}$ and Melastoma malabathricum Leaf at a dose of $50 \mathrm{mg} / \mathrm{kg}$.
\end{abstract}

Keywords: Liver, CYP450, antioxidant, free radicals

\section{INTRODUCTION}

Liver damage can be caused by infection and the activity of chemical compounds that enter the body with various action mechanisms. Liver damage begins with increased steatosis and eventually fibrosis of the liver which can cause death. Although the pathogenesis of fibrosis is unclear, it does not demand that reactive oxygen species (ROS) play a role in pathological changes in the liver, especially in cases of liver disease caused by alcohol and toxins. Cell membrane plays an important role in resisting the effects of ROS so that the process of peroxidation in unsaturated fatty acids on the membrane leads to decreased integrity and membrane function which implies serious pathological changes. Some of the body's natural protective mechanisms are involved in the reduction of liver damage caused by peroxidation. However, due to impaired protection or when increased SOR, additional protective mechanisms through antioxidant consumption are required. Many natural ingredients that exhibit antioxidant properties are advised in the prevention and treatment of liver diseases caused by free radicals (Panjaitan et al., 2011; Maulita et al., 2005).

In Indonesia in 1980- 2010, cirrhosis patients grew and caused mortality, $19.8 \%$
(1980), 22.4\% (1990), 24.3\% (year 2000), $24.8 \%$ (year 2010) per 100,000 deaths (Mokdad et al., 2014). From the data obtained by WHO, in 2012 Indonesia was ranked sixth in the world with a percentage of $3.2 \%$ as a cirrhosis of the liver causing death. In addition, deaths caused by the disease from 2000 to 2012 continue to increase (WHO, 2015) The use of medicinal plants for health benefits is increasing worldwide. Medicinal plants have a significant contribution to human health that is promotive, curative and rehabilitative, as well as in the prevention of disease (WHO, 2010).

Utilization derived from natural ingredients as a traditional medicine has begun to be developed. The use of natural or herbal ingredients plays a very important role in dealing with the problem of liver damage. Herbs are said to have hepatoprotective effects when its use is able to maintain the function of liver cells and help speed healing. In the last year the focus of research using herbs as hepatoprotective was evaluated through antioxidant mechanisms (Novianto, et al., 2016).

In Indonesia there are many kinds of plants that are believed to have the property as a hebal crop. Therefore, Indonesia has a great opportunity in processing herbs into 
products that have activity as a hepatoprotektor. Therefore, the expected review of this article can provide scientific information about herbal plants that have activity as a hepatoprotector.

\section{METHOD}

The review process of this article was carried out by collecting articles related to the topic from scientific worldwide journals. The articles were then screened and selected. Inclusion criteria are those published during 2013-2018. Other sources are used apart from journal data from WHO website and literature books.

\section{RESULT}

The results obtained from journal screening include effective doses of various plants and the activity of compounds that give effect as a hepatoprotector. The hepatoprotector activity test was performed by dividing the test animal into several groups, among which the positive control group, the negative control and the treatment group (the test group) gave effective dose results as a hepatoprotector agent.

Table. 1 Induction, Dosage, and Ingredients of Herbal Plant Compounds that Have Hepatoprotector Activity

\begin{tabular}{|c|c|c|c|c|c|}
\hline No. & Name of Spesies & Compound Content & Induction & $\begin{array}{c}\text { Dose } \\
\text { Effective } \\
\mathrm{mg} / \mathrm{kg}\end{array}$ & References \\
\hline 1 & Allium cepa & Flavonoid & Ethanol & 600 & (Eswar Kumar et al., 2013) \\
\hline 2 & Anacardium occidentale & Flavonoid, Saponin & $\mathrm{CCl} 4$ & 500 & $\begin{array}{l}\text { (Agbon, Ikyembe and Pwavodi, } \\
\text { 2014) }\end{array}$ \\
\hline 3 & Aquilaria agallocha & $\begin{array}{l}\text { Tannins, Flavonoids, } \\
\text { Phenolic }\end{array}$ & PCT & 400 & (Alam et al., 2017) \\
\hline 4 & Bauhinia purpurea & $\begin{array}{l}\text { Saponin, Flavonoid, } \\
\text { Tanin, Polifenol }\end{array}$ & PCT & 500 & (Yahya et al., 2013) \\
\hline 5 & Ceriops decandra (Griff.) & $\begin{array}{l}\text { Flavonoids, Catechin } \\
\text { Anthraquinone }\end{array}$ & $\mathrm{CCl} 4$ & 400 & $\begin{array}{l}\text { (Gnanadesigan, Ravikumar and } \\
\text { Anand, 2017) }\end{array}$ \\
\hline 6 & $\begin{array}{l}\text { Chenopodium bonus- } \\
\text { henricus } L \text {. }\end{array}$ & Flavonoid & $\mathrm{CCl} 4$ & 100 & $\begin{array}{l}\text { (Kokanova-Nedialkova et al., } \\
\text { 2017) }\end{array}$ \\
\hline 7 & Chonemorpha fragrans & Flavonoid & PCT, INH & 400 & $\begin{array}{l}\text { (Duraisankar, Devi and } \\
\text { Shanmugasundram, 2015) }\end{array}$ \\
\hline 8 & $\begin{array}{l}\text { Citrus hystrix \&Citrus } \\
\text { maxima }\end{array}$ & Flavonoid & PCT & 200 & $\begin{array}{l}\text { (Abirami, Nagarani and } \\
\text { Siddhuraju, 2015) }\end{array}$ \\
\hline 9 & Cosmos caudatus & Flavonoid, Quersetin & PCT & 1125 & (Rahman, 2009) \\
\hline 10 & Crocus sativus & Flavonoid & PCT & 20 & (Omidi et al., 2014) \\
\hline 11 & Curcuma longa & Flavonoid & Thioacetamide & 250 & (Salmah Ismail, 2013) \\
\hline 12 & Dendrophthoe petandra $\mathrm{L}$ & Flavonoid & $\mathrm{CCl} 4$ & 70 & $\begin{array}{l}\text { (Tristanti, Fatimawali and Bodhi, } \\
\text { 2013) }\end{array}$ \\
\hline 13 & Ecbolium viride roots & $\begin{array}{l}\text { Flavonoids, Alkaloids, } \\
\text { Sterols }\end{array}$ & PCT & 400 & $\begin{array}{l}\text { (Cheedella, Alluri and Ghanta, } \\
\text { 2013) }\end{array}$ \\
\hline 14 & Flacourtia montana & Flavonoids, Tannins & PCT & 200 & (Joshy et al., 2016) \\
\hline 15 & Gentiana cruciata L. & Flavonoid & $\mathrm{CCl} 4$ & 200 & (Mihailović et al., 2014) \\
\hline 16 & Gypsophila trichotoma & Saponarin & $\mathrm{CCl} 4$ & 80 & (Simeonova et al., 2014) \\
\hline 17 & Juniperus phoenicea & Flavonoids, Tannins & $\mathrm{CCl} 4$ & 250 & (Laouar et al., 2017) \\
\hline 18 & $\begin{array}{l}\text { Liquidambar styraciflua } \mathrm{L} . \\
\text { leaves }\end{array}$ & Flavonoid & $\mathrm{CCl} 4$ & 250 & (Eid et al., 2015) \\
\hline 19 & Lophatherum gracile & Flavonoid, Kumarin & $\mathrm{CCl} 4$ & 800 & Thomson, et al., 2016 \\
\hline 20 & $\begin{array}{l}\text { Lophatherum gracile } \\
\text { Leaves }\end{array}$ & Flavonoid, Chumarin & $\mathrm{CCl} 4$ & 800 & (He et al., 2016) \\
\hline
\end{tabular}




\begin{tabular}{|c|c|c|c|c|c|}
\hline 21 & $\begin{array}{l}\text { Macrothelypteris } \\
\text { torresiana (Gaudich.) }\end{array}$ & Flavonoid, Phenolic Acid & $\mathrm{CCl} 4$ & 300 & (Mondal et al., 2017) \\
\hline 22 & Maytenus robusta & Flavonoid & $\mathrm{CCl} 4$ & 100 & (Thiesen et al., 2017) \\
\hline 23 & $\begin{array}{l}\text { Melastoma } \\
\text { malabathricum Leaf }\end{array}$ & $\begin{array}{l}\text { Flavonoid, Saponins, And } \\
\text { Tannins }\end{array}$ & $\mathrm{PCT}, \mathrm{CCl} 4$ & 50 & (Kamisan et al., 2013) \\
\hline 24 & Morinda tinctoria & Flavonoids And Tannins & PCT & 150 & (Subramanian et al., 2013) \\
\hline 25 & Nigella sativa & Flavonoids, Silichristin & PCT & 250 & (Hamza and Al-Harbi, 2015) \\
\hline 26 & Oldenlandia herbacea & $\begin{array}{l}\text { Flavonoid, Fenol, } \\
\text { Saponin, Tanin }\end{array}$ & $\begin{array}{l}\text { D- } \\
\text { galactosamine }\end{array}$ & 200 & $\begin{array}{l}\text { (Pandian, Badami and Shankar, } \\
\text { 2013) }\end{array}$ \\
\hline 27 & $\begin{array}{l}\text { Rhodiola } \\
\text { imbricatarhizome }\end{array}$ & Flavonoids, Coumarins & PCT & 400 & $\begin{array}{l}\text { (Senthilkumar, Chandran and } \\
\text { Parimelazhagan, 2014) }\end{array}$ \\
\hline 28 & $\begin{array}{l}\text { Solanum xanthocarpum \& } \\
\text { Juniperus communis }\end{array}$ & Phenolic, Flavonoid & $\begin{array}{l}\text { PCT, } \\
\text { Azithromycin }\end{array}$ & 400 & (Singh et al., 2016) \\
\hline 29 & Tetrapleura tetraptera & Flavonoid & $\mathrm{CCl} 4$ & 300 & (Campanulatus and Tubers, 2009) \\
\hline 30 & Uncaria gambir Roxb. & Katekin & $\mathrm{CCl} 4$ & 30 & $\begin{array}{l}\text { (Hasti, Muchtar and Bakhtia, } \\
\text { 2012) }\end{array}$ \\
\hline
\end{tabular}

\section{DISCUSSION}

\begin{abstract}
From the various types of plants studied and known to provide hepatoprotector activity, all these plants contain antioxidants derived from secondary metabolite compounds namely flavonoids. The other secondary metabolite compounds found in some plants such as coumarin, catechins, saponins, phenol compounds and others.
\end{abstract}

Antioxidants are one of the targets of the hepatoprotective mechanism. Damage to cell membranes and proteins is a sign of oxidative stress caused by free radicals (Panjaitan, et al., 2007). Therefore, antioxidants are needed to convert free radicals into non-reactive compounds.

The usual method of testing hepatoprotector activity can be either in vivo or in vitro. In vivo is done by giving test preparation to the animal by being divided into several groups to see the difference of result from each group to be tested.

From Table 1 it can be seen that Crocus sativus gave the largest hepatoprotector activity at a dose of $20 \mathrm{mg} /$ $\mathrm{kg}$, followed by Uncaria gambier Roxb. with a dose of $30 \mathrm{mg} \mathrm{/} \mathrm{kg}$ and Melastoma malabathricum Leaf at a dose of $50 \mathrm{mg} / \mathrm{kg}$.

Substances used to induce liver damage are called hepatotoxins, commonly used Paracetamol, Carbon tetrachloride
(CCl4), D-Galactosamine, and Thioacetamide. In damaged liver organel damage and cell membranes that can cause ALT and AST enzymes are released into the blood from subel organelles and cytosols. Therefore, the levels of enzymes in the blood vessels will increase (Novianto, 2016)

Based on a review of the source of review data obtained, parameters examined in the test hepatoprotektor, including the biochemical and histopathological parameters. Biochemical parameters include AST, ALT, ALP, total bilirubin, total cholesterol, total glycerides, serum proteins, and antioxidant enzyme activity. As for histopathology by looking at damage to hepatocytes using a microscope.

Increased total bilirubin levels can be caused by a leak of bilirubin from ductuli cells or liver cells that cause bilirubin to enter the bloodstream. Decreased protein levels are caused because liver cells are damaged so that the ability to synthesize proteins decreases. Increased ALP can be caused by the presence of kolestatis, and in extrabiliary obstruction or intrabiliar this enzyme has increased 3-10 times than normal. Increased ALT in the blood is caused by damage to liver cells and skeletal muscle cells. While the AST treatment is caused by severe liver damage accompanied by necrosis (Panjaitan et al., 2011) 


\section{CONCLUSION}

Many plants have been reported to have hepatoprotector activity with its ability as an antioxidant. This antioxidant compound is one of them is flavonoids. Of the 30 plants studied, Crocus sativus gave the largest hepatoprotector activity at a dose of $20 \mathrm{mg} /$ $\mathrm{kg}$, followed by Uncaria gambier Roxb. with a dose of $30 \mathrm{mg} \mathrm{/} \mathrm{kg}$ and Melastoma malabathricum Leaf at a dose of $50 \mathrm{mg} / \mathrm{kg}$.

\section{REFERENCE}

Abirami, A., Nagarani, G. and Siddhuraju, P. (2015) 'Hepatoprotective effect of leaf extracts from Citrus hystrix and C. maxima against paracetamol induced liver injury in rats', Food Science and Human Wellness. Beijing Academy of Food Sciences., 4(1), pp. 35-41. doi: 10.1016/j.fshw.2015.02.002.

Agbon, A., Ikyembe, D. and Pwavodi, C. (2014) 'Hepatoprotective effect of methanolic leaf extract of anacardium occidentale (cashew) on carbon-tetrachloride-induced liver toxicity in wistar rats', Sub-Saharan African Journal of Medicine, 1(3), p. $124 . \quad$ doi: 10.4103/23845147.138938 .

Alam, J. et al. (2017) 'Hepatoprotective potential of ethanolic extract of Aquilaria agallocha leaves against paracetamol induced hepatotoxicity in SD rats', Journal of Traditional and Complementary Medicine. Elsevier Ltd, 7(1), pp. 9-13. doi: 10.1016/j.jtcme.2015.12.006.

Campanulatus, A. and Tubers, R. (2009) 'Antioxidant and Hepatoprotective Activity of Ethanolic and Aqueous Extracts of', 66(4), pp. 423-428.

Cheedella, H. K., Alluri, R. and Ghanta, K. M. (2013) 'Hepatoprotective and antioxidant effect of Ecbolium viride (Forssk.) Alston roots against paracetamol-induced hepatotoxicity in Albino Wistar rats', Journal of Pharmacy Research. Elsevier B.V,
7(6), pp. 496-501. doi: 10.1016/j.jopr.2013.06.001.

Duraisankar, M., Devi, M. and Shanmugasundram, P. (2015) 'Hepatoprotective activity of alcoholic extract of chonemorpha fragrans root in against paracetamol and Isoniazid-induced liver damage in rats', International Journal of PharmTech Research, 8(7), pp. 232242.

Eid, H. H. et al. (2015) 'Hepatoprotective and antioxidant polyphenols from a standardized methanolic extract of the leaves of Liquidambar styraciflua L.', Bulletin of Faculty of Pharmacy, Cairo University. Faculty of Pharmacy, Cairo University, 53(2), pp. 117-127. doi: 10.1016/j.bfopcu.2015.05.002.

Eswar Kumar, K. et al. (2013) 'In vitro antioxidant activity and in vivo hepatoprotective activity of aqueous extract of Allium cepa bulb in ethanol induced liver damage in Wistar rats', Food Science and Human Wellness. Beijing Academy of Food Sciences., 2(3-4), pp. 132-138. doi: 10.1016/j.fshw.2013.10.001.

Gnanadesigan, M., Ravikumar, S. and Anand, M. (2017) 'Hepatoprotective activity of Ceriops decandra (Griff.) Ding Hou mangrove plant against $\mathrm{CCl} 4$ induced liver damage', Journal of Taibah University for Science. Taibah University, 11(3), pp. 450-457. doi: 10.1016/j.jtusci.2016.07.004.

Hamza, R. Z. and Al-Harbi, M. S. (2015) 'Amelioration of paracetamol hepatotoxicity and oxidative stress on mice liver with silymarin and Nigella sativa extract supplements', Asian Pacific Journal of Tropical Biomedicine. Elsevier (Singapore) Pte Ltd, 5(7), pp. 521-531. doi: 10.1016/j.apjtb.2015.03.011.

Hasti, S., Muchtar, H. and Bakhtia, A. (2012) 'Uji Aktivitas Hepatoproteksi dan Toksisitas Akut dari Ekstrak Gambir 
Terstandarisasi', Jurnal Penelitian Farmasi indonesia,

1(Septembern2012), pp. 34-38.

$\mathrm{He}, \mathrm{Q}$. et al. (2016) 'Hepatoprotective activity of Lophatherum gracile leaves of ethanol extracts against carbon tetrachloride-induced liver damage in mice', International Journal of Pharmacology. Science Alert, 12(4), pp. 387-393. doi: 10.3923/ijp.2016.387.393.

Joshy, C. et al. (2016) 'Hepatoprotective, antiinflammatory and antioxidant activities of Flacourtia montana J. Grah leaf extract in male Wistar rats', Bulletin of Faculty of Pharmacy, Cairo University. Faculty of Pharmacy, Cairo University, 54(2), pp. 209-217. doi: 10.1016/j.bfopcu.2016.06.001.

Kamisan, F. H. et al. (2013) 'Hepatoprotective Activity of Methanol Extract of Melastoma malabathricum Leaf in Rats', JAMS Journal of Acupuncture and Meridian Studies. Elsevier Korea LLC, 6(1), pp. 52-55. doi: 10.1016/j.jams.2012.08.002.

Kokanova-Nedialkova, Z. et al. (2017) 'Chenopodium bonus-henricus L. - A source of hepatoprotective flavonoids', Fitoterapia. Elsevier B.V., 118, pp. 13-20. doi: 10.1016/j.fitote.2017.02.001.

Laouar, A. et al. (2017) 'Potential antioxidant properties and hepatoprotective effects of Juniperus phoenicea berries against $\mathrm{CCl} 4$ induced hepatic damage in rats', Asian Pacific Journal of Tropical Medicine. Elsevier B.V., 10(3), pp. 263-269. doi: 10.1016/j.apjtm.2017.03.005.

Maulita, A. S. et al. (2005) 'Uji Aktivitas Ekstrak Buah Merah ( Pandanus conoideus ) sebagai Hepatoprotektor pada Hati Mencit Galur Swiss yang Diinduksi dengan'.

Mihailović, V. et al. (2014) 'Hepatoprotective effects of secoiridoid-rich extracts from Gentiana cruciata L. against carbon tetrachloride induced liver damage in rats', Food Funct., 5(8), pp. 1795-1803. doi: 10.1039/C4FO00088A.

Mondal, S. et al. (2017) 'Hepatoprotective activity of Macrothelypteris torresiana (Gaudich.) aerial parts against $\mathrm{CCl} 4$-induced hepatotoxicity in rodents and analysis of polyphenolic compounds by HPTLC', Journal of Pharmaceutical Analysis. Elsevier B.V., 7(3), pp. 181-189. doi: 10.1016/j.jpha.2016.12.001.

Omidi, A. et al. (2014) 'Hepatoprotective effect of Crocus sativus ( saffron ) petals extract against acetaminophen toxicity in male Wistar rats', Avicenna J Phytomed, 4(5), pp. 330-336.

Pandian, S., Badami, S. and Shankar, M. (2013) 'Hepatoprotective activity of methanolic extract of Oldenlandia herbacea against $D$ - galactosamine induced rats', International Journal of Applied Research in Natural Products, 6(1), pp. 16-19.

Panjaitan, R. G. P. et al. (2011) 'Aktivitas Hepatoprotektor Ekstrak Metanol Akar Pasak Bumi dan Fraksi-Fraksi Turunannya', Jurnal Veteriner, 12(4), pp. 319-325.

Rahman, A. F. (2009) 'Cosmos caudatus)', 3(1), pp. 6-15. doi: Universitas Airlangga.

Salmah Ismail, S. S. A. and S. G. S. M. S. M. A. A. A. S. A. (2013) 'Hepatoprotective effect of ethanolic extract of Curcuma longa on thioacetamide induced liver cirrhosis in rats', $B M C$ Complementary and Alternative Medicine, 13(56). Available at: http://www.biomedcentral.com/147 2-6882/13/56.

Senthilkumar, R., Chandran, R. and Parimelazhagan, T. (2014) 'Hepatoprotective effect of Rhodiola imbricata rhizome against paracetamol-induced liver toxicity in rats', Saudi Journal of Biological 
Sciences. King Saud University, 21(5), pp. 409-416. doi: 10.1016/j.sjbs.2014.04.001.

Simeonova, R. et al. (2014) 'Protective effects of the apigenin-O/C-diglucoside saponarin from Gypsophila trichotoma on carbone tetrachloride-induced hepatotoxicity in vitro/in vivo in rats', Phytomedicine. Elsevier $\mathrm{GmbH}$., 21(2), pp. 148-154. doi: 10.1016/j.phymed.2013.07.014.

Singh, H. et al. (2016) 'Synergistic hepatoprotective potential of ethanolic extract of Solanum xanthocarpum and Juniperus communis against paracetamol and azithromycin induced liver injury in rats', Journal of Traditional and Complementary Medicine. Elsevier Ltd, 6(4), pp. 370-376. doi: 10.1016/j.jtcme.2015.07.005.

Subramanian, M. et al. (2013) 'Hepatoprotective effect of leaves of Morinda tinctoria Roxb. against paracetamol induced liver damage in rats', Drug Invention Today. Elsevier Ltd, 5(3), pp. 223-228. doi: 10.1016/j.dit.2013.06.008.

Thiesen, L. C. et al. (2017) 'Hepatoprotective effect of Maytenus robusta Reiss extract on $\mathrm{CCl} 4$-induced hepatotoxicity in mice and HepG2 cells', Regulatory Toxicology and Pharmacology, 86, pp. 93-100. doi: 10.1016/j.yrtph.2017.02.023.

Tristanti, I., Fatimawali and Bodhi, W. (2013) 'Uji Efek Hepatoprotektor Ekstrak Etanol Daun Benalu Langsat (Dendrophthoe petandra (L.) Miq.) terhadap Kadar Malonaldehid (MDA) pada Hati Tikus Putih Jantan Galur Wistar yang Diinduksi Karbon Tetraklorida (CCl4)', Jurnal IImiah Farmasi, 2(3), pp. 75-78.

Yahya, F. et al. (2013) 'Hepatoprotective activity of methanolic extract of bauhinia purpurea leaves against paracetamol-induced hepatic damage in rats', Evidence-based Complementary and Alternative Medicine, 2013.2 doi: 10.1155/2013/636580.

WHO (World Health Organization). 2010. Traditional herbal remedies for primary health care. [Online] Available from: http://apps.who.int/iris/handle/106 65/206024 [Accessed on 13th March, 2018].

WHO (World Health Organization). 2015. Indonesia : WHO Statistical Profile. [Online] Available from:http://www.who.int/gho/en/ [Accessed on 13th March, 2018]. 